研究速報

\title{
新興境界領域研究の現況 —科学研究費助成事業の分類を用いた分析一 The present state analysis of emerging interdisciplinary research areas: An analysis based on a classified table of Grant-in-Aid for Scientific Research
}

\author{
中渡瀬 秀一 †* \\ Hidekazu NAKAWATASE ${ }^{\dagger *}$
}

$\dagger$ 国立情報学研究所

National Institute of Informatics

干 101-8430 東京都千代田区一ツ橋 2-2-1

E-mail: nakawtse@nii.ac.jp

*連絡先著者

本速報では学術における境界領域研究の現況を分析する方法として近年の科研費データに注目し，これ を分析した結果を報告する。

In recent years, there has been a growing interest in interdisciplinary research. We propose a method to analyze such research activities using data of Grant-in-Aid for Scientific Research. And we show the present state of an interdisciplinary research by analyzing the data.

キーワード: 学際研究, 境界領域研究, 科学研究費

Interdisciplinary Research, Multidisciplinary Research, Scientific research fund

\section{1 はじめに}

異なる研究分野の知識を横断的に集結させて研究 課題の解決を目指す境界領域研究 1 への関心が高 まっている ${ }^{11]}$.これには単一の学問分野だけでは解 決が難しい社会課題（気候変動・環境問題など）の 顕在化がその背景にある。このような新しい境界領 域は未開な分野であるために開拓の余地が大きく, 既に長く手掛けられてきた領域より急速に成長する 研究分野になることが期待される.

ところがこのような境界領域研究の現況を直接的 に測ることは困難であった ${ }^{[1]}$ 。 それに対し我々は科 研費（科学研究費助成事業）による融合的分野に対 する助成，特に一部種目で近年開始された領域網羅 的な助成状況を分析することで萌芽的な新興境界領 域研究の現況が把握できることを示す.

従来, 境界領域研究を計量的に分析するために引 用分析が用いられてきた ${ }^{[2,1]}$ 。これはある分野に おける論文の引用・被引用文献の分野多様性から学 際度を測るものである。この分析は，ある研究分野 に関する参照・被参照分野の比率や種類を明らかに

\footnotetext{
1学際的研究などによって形成される領域研究
}

することができる。このことから間接的に参照・被 参照の多い分野との間に境界領域研究の存在が示唆 される.つまりこの方法では直接的に境界領域研究 を検知することができない，それを確実に行うには 個々の研究が境界領域的であるかを個別に判断する 必要がある.このように境界領域研究の集計は容易 ではない.

これに対し科研費では提案型の助成（新学術領域 研究）や既存分類の中にある認知科学や環境学のよ うな境界領域の細目 ${ }^{2}$ を通じて一部の境界領域分野 に応募することが可能である．ただし提案型は少数 であり，既存細目に含まれる境界領域はすでに認知 度が高いものである，そのため萌芽段階にある新興 境界領域研究を広範に捉えることはできなかった。

その他，非定量的かつ間接的に境界領域研究の現 状を把握する方法としてアンケートによる「研究者 の意識調査」も実施されてきた。これは文部科学省 科学技術・学術政策研究所が実施している「科学技 術の状況に係る総合的意識調査」[3]に含まれる「分 野連携・融合領域研究への取組」の定点観測 (2006 〜2010 年)である.ここでは「分野連携の状況」と

${ }^{2}$ 科研費における研究分野の分類項目 
して

「分野連携・融合領域研究への取り組みについては、 第 3 期科学技術基本計画期間中に大きな状況の変化 は見られなかった。今後、人文・社会科学と自然科学 の知の統合を進めるべきであるという認識が 2006 年度調査から継続している。しかし、現状では、人 文・社会科学と自然科学の知の統合は弱いという結 果となっている」

と研究関係者の心象がまとめられている。このよう に新興境界領域研究それ自体の広範な活動現状を 直接定量的に分析したものは知りうる限り存在しな かった.

その後この状況に変化が訪れる. 契機となったの は科研費における新興・融合的な分野に対する研究 計画の審査導入 (若手研究 (B) で平成 25 年度実 施分以降）である ${ }^{[4]}$ 。これによって研究者は境界領 域研究であることを明示して，そのための審査に応 募することが可能となった，具体的には，既存の細 目から境界領域を構成する 2 細目を指定して応募す る.このことは同時に, どの研究計画が新興境界領 域に属するのかを直接把握できるようになったこと も意味している．また国内最大規模の助成金である 科研費は学術分野のほぼ全域をカバーするため, こ れによって国内の新興境界領域研究の大半がカバー されると考えられる.

本稿では上記に関する科研費のデータを入手し， 分析することで新興境界領域研究の実施数, 各分野 におけるその比率，その比率の分野間比較などから その現況を定量的に取りまとめ, その特徵について 分析結果を速報する. 以下 2 章では分析方法につい て説明する. 次に 3 章では分析結果と考察を述べ, 最後に 4 章で本稿をまとめる.

\section{2 方法}

本分析では科研費の種目である若手研究（B）で 境界領域研究としての応募が可能になった年度から 3 年分の研究計画データ（平成 $25 \sim 27$ 年度）を用い た. まずこれら研究計画のうち単一細目に応募され ているものを従来領域（既に確立されて細目名に含 まれる環境学のような境界領域を含む）の研究， 2 細目に応募されているものを新興境界領域研究（以 下, 単に境界領域研究) として各細目別の集計を行 う. 次に後述する各種視点から細目の分類構造を考
慮して分析する. 以下にこの分類構造（系統的に階 層分類されている）と分析視点について説明する.

\section{科研費における研究分野の分類}

科研費では研究分野を「系・分野・分科・細目」 の 4 階層で分類している. 平成 $25 \sim 27$ 年度の場合 は以下の通りである ${ }^{[5]}$. なお以後混同の恐れがあ る場合にはこの分類の意味で分野を指す場合に「分 野」と明記する。

「系」総合系・人文社会系・理工系・生物系の 4 系 「分野」各系ごとに総合分野または複合分野を含む $3 \sim 4$ の分野（例えば生物系では総合生物・ 生物学・農学・医歯薬学)

「分科」哲学・法学・数学・薬学など 79 の分科

「細目」分科を細分化した 300 余りの細目

境界領域として応募する場合はこの分類から 2 細目 を選ぶことにより形式的には 90,000 以上の境界領 域から選択することが可能である．上記の分類にお いて総合に関する「系」や「分野」に属する細目, 「細目」の中でも応用的な細目は領域横断的な性格 を持つため，そのような細目で境界領域が多く形成 されることが予想される，その点にも注目して分析 する.

\section{分析視点}

以下の視点から分析を行った.

1:境界領域研究の割合 各細目における研究計画 (従 来領域研究とその細目を含む境界領域研究）に 対する境界領域研究の割合でその活発度を測つ た。さらに階層別にもそれを算出し「系・分 野・分科・細目」を超えた連携の度合いの差 も考察する.

2:細目毎の境界領域の種類 各細目が境界領域を通 じてつながる他の細目の種類から細目ごとの 境界領域の多様性を測る。

$3:$ 活発な境界領域 全ての境界領域研究の中で採択 数の多い境界領域を比較する.

\section{3 結果・考察}

それぞれの分析結果を示し，その考察を行う. 
表 1: 境界領域研究の割合上位 $5 \%$ 細目

\begin{tabular}{|c|c|c|c|c|}
\hline $\begin{array}{c}\text { 細目 [系](境界領域 } \\
\text { 研究の割合) }\end{array}$ & $\begin{array}{l}\text { 他系細目との } \\
\text { 境界領域割合 }\end{array}$ & $\begin{array}{l}\text { 他分野細目との } \\
\text { 境界領域割合 }\end{array}$ & $\begin{array}{l}\text { 他分科細目との } \\
\text { 境界領域割合 }\end{array}$ & $\begin{array}{l}\text { 同分科細目との } \\
\text { 境界領域割合 }\end{array}$ \\
\hline ジェンダー [人](0.707) & 0.171 & 0.512 & 0.024 & 0.000 \\
\hline 応用人類学 [生](0.667) & 0.583 & 0.083 & 0.000 & 0.000 \\
\hline 子ども学 [総](0.649) & 0.365 & 0.054 & 0.230 & 0.000 \\
\hline 思想史 [人](0.648) & 0.037 & 0.148 & 0.259 & 0.204 \\
\hline 地域研究 [人] $(0.648)$ & 0.066 & 0.549 & 0.033 & 0.000 \\
\hline 文学一般 $[$ 人 $](0.636)$ & 0.000 & 0.000 & 0.091 & 0.545 \\
\hline 基盤・社会脳科学 [総](0.618) & 0.436 & 0.091 & 0.055 & 0.036 \\
\hline 持続可能システム [総](0.611) & 0.472 & 0.000 & 0.028 & 0.111 \\
\hline 結晶工学 [理] $(0.607)$ & 0.000 & 0.429 & 0.036 & 0.143 \\
\hline 医療技術評価学 [総] $(0.600)$ & 0.450 & 0.050 & 0.000 & 0.100 \\
\hline デバイス関連化学 [理] $(0.585)$ & 0.000 & 0.293 & 0.171 & 0.122 \\
\hline 家政 · 生活学一般 [総] $(0.583)$ & 0.250 & 0.028 & 0.139 & 0.167 \\
\hline 脳計測科学 [総] $(0.581)$ & 0.258 & 0.226 & 0.032 & 0.065 \\
\hline ナノバイオサイエンス [理] (0.579) & 0.263 & 0.105 & 0.053 & 0.158 \\
\hline 環境影響評価 [総] $(0.571)$ & 0.229 & 0.000 & 0.200 & 0.143 \\
\hline 生体医工学 ·生体材料学 [総] (0.567) & 0.408 & 0.045 & 0.032 & 0.083 \\
\hline
\end{tabular}

[総] 総合系,[人] 人文社会系, [理] 理工系, [生] 生物系

右 4 列中の太数字は各行右 4 列において最大の值

\section{1 境界領域研究の割合}

まず境界領域研究の占める割合が高い順に細目の 上位 $5 \%$ （16 細目）を表 1 に示す. 同表は最左列か ら順に，その細目において境界領域研究が研究全体 に占める割合，同割合のうち同細目の属する「系」 と異なる「系」に属する細目との境界領域研究が占 副合, 以右も同様に他「分野」, 他分科, 同分 科のそれらを示す。

表内の各細目においてはそれぞれの全研究計画数 のうち境界領域研究であるものが過半数を超えてい

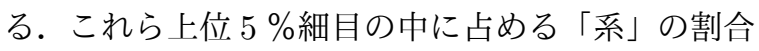
では, 総合系 8 細目 $(50 \%)$, 人文社会系 4 細目 $(25$ $\%)$, 理工系 3 細目 $(18.8 \%)$, 生物系 1 細目 $(6.3 \%)$ の順に高くなっている.

前述したように系として学問横断的な性格を持つ 総合系の細目が境界領域研究比率の大きい細目群 で半数を占めている．また人文社会系の細目である ジェンダー, 地域研究は「分野」において総合人文 社会に属し, 理工系の結晶工学, ナノバイオサイエ ンスもまた「分野」においては総合理工に属してい る.このように「系」や「分野」で総合的性格を持 つ細目 (総合系 8 細目, 総合人文社会 2 細目と総合 理工 2 細目) が上位 $5 \%$ 細目全体（16 細目）の 75
\%を占める.これら以外では応用人類学とデバイス 関連化学は応用的な細目である. 残る思想史と文学 一般の特徵は同「分野」や同分科の細目との境界領 域研究が大半を占めることである.これに対し総合 的性格を持つ細目では逆に他系や他「分野」の細目 との境界領域研究が多く, この点で両者は対照的で ある。

さらに境界を成す細目の選好にも特徴がある．総 合系細目においては全て他系の細目との境界領域研 究の割合が最大であり (表 1 左から 2 列目の太数字), 総合人文社会「分野」細目のジェンダー, 地域研究 では (同系) 他「分野」の細目との境界領域研究の 割合が最大である ${ }^{3}$.このように「系・分野」の性 質 (総合性) が境界領域として選好される細目の階 層に影響している。

次に境界領域研究の占める割合が低い細目の下 位 $5 \%$ を表 2 に示す．この中に総合系の細目は見ら れず，属する系の割合は高いものから生物系 $(62.5$ $\%)$, 理工系 $(18.8 \%)$, 人文社会系 $(18.8 \%)$ と上位 $5 \%$ の場合と逆順である. この中で大半占める生物 系の 10 細目は殆どが外科系臨床医学 (7 細目) に集 中している (他は歯学 2 . 農学 1 細目). 理工系で

3総合理工「分野」細目では他系または (同系) 他「分野」の 細目との境界領域研究の割合が最大である 
は素粒子, 代数学や核融合学, 人文社会系では英米 文学, 会計学や刑事法学が他分野に比べ細目を越え た分野連携に関しては積極的でないことを示す結果 となっている.

表 2: 境界領域研究割合が下位 $5 \%$ 以内の細目

\begin{tabular}{|c|c|}
\hline 細目 [系] & $\begin{array}{c}\text { 境界領域研究 } \\
\text { の割合 }\end{array}$ \\
\hline $\begin{array}{l}\text { 素粒子・原子核・ } \\
\text { 宇宙線・宇宙物理 [理] }\end{array}$ & 0.100 \\
\hline 小児外科学 [生] & 0.100 \\
\hline 麻酔科学 [生] & 0.097 \\
\hline 保存治療系歯学 [生] & 0.094 \\
\hline 矯正 · 小児系歯学 [生] & 0.086 \\
\hline 代数学 [理] & 0.081 \\
\hline 英米 ·英語圏文学 [人] & 0.080 \\
\hline 形成外科学 [生] & 0.076 \\
\hline 泌尿器科学 [生] & 0.075 \\
\hline 会計学 [人] & 0.069 \\
\hline 刑事法学 [人] & 0.069 \\
\hline 眼科学 [生] & 0.064 \\
\hline 呼吸器外科学 [生] & 0.057 \\
\hline 園芸科学 [生] & 0.032 \\
\hline 核融合学 [理] & 0.029 \\
\hline 耳鼻咽喉科学 [生] & 0.026 \\
\hline
\end{tabular}

\section{2 細目毎の境界領域の種類}

次に各細目が関わる境界領域の種類について考察 する．境界領域は 2 細目のペアによって定まる領域 である.ある細目とペアになっている他方の細目を すべて集計することで，その細目が関連する領域の 種類をカウントした．そのような境界領域種類で上 位 $5 \%$ に含まれる細目を表 3 に示す。これらの細目 中に理工系の細目は見られず，属する系の割合は高 いものから生物系 $(50 \%)$, 総合系 $(31.3 \%)$, 人文 社会系 $(18.8 \%)$ と 3.1 節の場合とは異なり生物系 が最大である。

ある細目で採択される境界領域の研究計画数は必 ずその細目での境界領域の種類以上となる.そこで 前者の規模と後者との比較を行った。その結果，表 3 に挙げた細目については (境界領域) 研究採択数の 視点でも全て上位 $10 \%$ 以内に含まれていた。特に
これらの細目の $62.5 \%$ （表中で*の細目）は採択 数においても上位 $5 \%$ 以内に含まれるものである. このように採択数と境界領域種類との間には相関が 見られる。

表 3: 境界領域の種類が上位 $5 \%$ 以内の細目

\begin{tabular}{|c|c|c|}
\hline 細目 [系] & $\begin{array}{c}\text { 関連する境界 } \\
\text { 領域の種類 }\end{array}$ & \\
\hline 生体医工学 - 生体材料学 [総] & 43 & $*$ \\
\hline リハビリテーション科学・ & & \\
\hline 福祉工学 [総] & 36 & $*$ \\
\hline 医化学一般 [生] & 28 & $*$ \\
\hline 地域研究 [人] & 27 & $*$ \\
\hline 腫瘍生物学 [生] & 27 & $*$ \\
\hline 衛生学 ·公衆衛生学 [生] & 27 & $*$ \\
\hline 社会福祉学 [人] & 26 & $*$ \\
\hline 知能情報学 [総] & 25 & $* *$ \\
\hline 社会システム工学・ & & \\
\hline 安全システム [総] & 25 & $* *$ \\
\hline 社会学 [人] & 25 & * \\
\hline 腫瘍治療学 [生] & 25 & $*$ \\
\hline 分子生物学 [生] & 24 & $* *$ \\
\hline 細胞生物学 [生] & 24 & $* *$ \\
\hline 小児科学 [生] & 24 & $*$ \\
\hline 免疫学 $[$ 生] & 23 & $* *$ \\
\hline 知覚情報処理 [総] & 22 & $* *$ \\
\hline
\end{tabular}

[総] 総合系, [人] 人文社会系, [生] 生物系

$* / * *$ : 研究計画採択数が上位 $5 / 10 \%$ 以内の細目

\section{3 活発な境界領域}

最後に境界領域別の活動度について考察する．指 定可能な境界領域は形式上 90,000 種類以上存在す る.このうち採択された全ての境界領域研究によっ てカバーされる境界領域は 1,715 種類であった。こ れら全ての中から採択件数の多い境界領域の上位 10 件を表 4 に示す.

領域を構成する系の組合せでは共に総合系が 40 $\%$ ，共に人文社会系が $30 \%$ ，共に生物系が $10 \%$ と 同系の組合せで上位 10 件の $80 \%$ を占める. 残り は総合系と生物系, 総合系と人文社会系で総合系に 関連する。つまり活発な境界領域は系を横断しない 細目同士の領域かもしくは総合系に関連する領域で ある．さらに分科のレベルで比較すると，同分科内 
表 4: 採択件数の多い境界領域研究の上位 10 件

\begin{tabular}{|c|c|c|}
\hline $\begin{array}{l}\text { 採択 } \\
\text { 件数 }\end{array}$ & 細目 1（系/分野/分科/細目） & 細目 2（系/分野/分科/細目） \\
\hline 21 & 総合系/ 情報学/人間情報学 /認知科学 & 人文社会系 /社会科学 / 心理学/ 実験心理学 \\
\hline 20 & 総合系/複合領域/人間医工学/リハビリテーション科学・福祉工学 & 総合系/複合領域/健康・スポーツ科学/応用健康科学 \\
\hline 20 & 総合系 /複合領域/健康・スポーツ科学/ 身体教育学 & 総合系/複合領域/ 健康・スポーツ科学/ スポーツ科学 \\
\hline 19 & 人文社会系/ 総合人文社会 /地域研究 /地域研究 & 人文社会系 人文学/ 文化人類学/ 文化人類学・民俗学 \\
\hline 15 & 総合系 /複合領域 /生活科学/ 食生活学 & 生物系/ 農学/ 農芸化学 / 食品科学 \\
\hline 14 & 総合系 /複合領域 /健康・スポーツ科学 /スポーツ科学 & 総合系 /複合領域 /健康・スポーツ科学/応用健康科学 \\
\hline 13 & 人文社会系/ 社会科学/社会学/社会福祉学 & 人文社会系/ 社会科学/ 心理学 /臨床心理学 \\
\hline 12 & 総合系 /複合領域 /科学教育·教育工学 /教育工学 & 総合系/情報学 /情報学フロンティア/学習支援システム \\
\hline 11 & 生物系 /医歯薬学/内科系臨床医学/ 小児科学 & 生物系/ 医歯薬学/ 内科系臨床医学/ 胎児·新生児医学 \\
\hline 11 & 人文社会系 /社会科学 /経済学 /経済政策 & 人文社会系 /社会科学 /経済学 / 財政・公共経済 \\
\hline
\end{tabular}

細目同士の領域が上位 10 件の $40 \%$ を占めている. これは同系の組合せによる境界領域の半分弱に相当 する.

\section{4 まとめ}

本稿では境界領域研究の現況を分析するために, 近年導入された科研費による新興・融合分野に対す る助成に注目した。その記録を利用して従来の引用 分析では間接的に分析することしかできなかった新 興境界領域研究を直接定量的に分析する方法を示し た。実際にこの方法でデータ分析を行い，その結果 について分野の性質や階層に注目した考察を行った。

分析の結果, 総合的な分野, 応用的分野において 境界領域研究が活発であること, 関連する境界領域 の種類はその研究分野の活動規模に応じて増大して いること，採択件数が多い活発な境界領域は同系の 細目同士から形成される領域でありその半数弱は同 分科の細目同士の領域であること 4 等が示された。

現在, 取得できる分析用データは 2 期間分である ため時系列的な分析を行うためには十分ではない. しかし今後も継続的に蓄積を進めて境界領域研究の 変化・発展も時系列分析する予定である，そのため にも 2 細目を選定した審査が今後も継続されること を期待する.なお細目の分類については約 10 年ご とに大きく見直されてきた。そこで今後の境界領域 研究動向が次回の分類再編 ${ }^{5}$ に与える影響について も明らかにしてゆきたい.

\footnotetext{
4 人文・社会科学と自然科学の知の統合の弱さを定量面から 示唆している

5 平成 30 年度から審査方式を見直す科研費審査システム改革 2018 が検討されている.
}

\section{謝辞}

本研究にあたり, 国立情報学研究所から科研費 データの提供を受けた。なお本研究の一部は科研費 挑戦的萌芽研究（課題番号：16K12833）の助成を 受けて行われたものである.

\section{参考文献}

[1] Van Noorden, Richard: "Interdisciplinary research by the numbers", Nature, Vol. 525, No. 7569, pp. 306-307, 2015.

[2] Qin, Jian; Lancaster, Fredrick W; Allen, Bryce: "Types and levels of collaboration in interdisciplinary research in the sciences", JASIS, Vol. 48, No. 10, pp. 893-916, 1997.

[3] 科学技術政策研究所：「科学技術の状況に係る 総合的意識調査（定点調査 2010）「科学技術シ ステムの課題に関する代表的研究者・有識者の 意識定点調査」「科学技術分野の課題に関する 第一線級研究者の意識定点調査」総合報告書」, NISTEP REPORT, No. 146, 2011.

[4] 日本学術振興会：「平成 25 年度科学研究費 助成事業-科研費-の公募について」，2012. https://www.jsps.go.jp/j-grantsinaid/ 02_koubo/h25_koubo/data/25koubotsuchi.pdf.

[5] 日本学術振興会：「平成 28 年度 系・分野・分科・細目表」, 2016. https://www.jsps.go.jp/j-grantsinaid/ 03_keikaku/data/h28/h28_koubo_06.pdf. 